\title{
Organization of Six-Cylinder Tractor Diesel Working Process
}

\author{
G. M. Kuharonak ${ }^{1)}$, M. Klesso ${ }^{2)}$, A. Predko' ${ }^{2)}$ D. Telyuk ${ }^{2)}$ \\ ${ }^{1)}$ Belarusian National Technical University (Minsk, Republic of Belarus), \\ ${ }^{2)}$ OJSC “Minsk Motor Plant” Holding Managing Company (Minsk, Republic of Belarus) \\ (C) Белорусский национальный технический университет, 2021 \\ Belarusian National Technical University, 2021
}

\begin{abstract}
The purpose of the work is to consider the organization of the working process of six-cylinder diesel engines with a power of 116 and $156 \mathrm{~kW}$ and exhaust gas recirculation. The following systems and components were used in the experimental configurations of the engine: Common Rail BOSCH accumulator fuel injection system with an injection pressure of $140 \mathrm{MPa}$, equipped with electro-hydraulic injectors with seven-hole nozzle and a $500 \mathrm{~mm}^{3}$ hydraulic flow; direct fuel injection system with MOTORPAL fuel pump with a maximum injection pressure of $100 \mathrm{MPa}$, equipped with MOTORPAL and AZPI five-hole nozzle injectors; two combustion chambers with volumes of 55 and $56 \mathrm{~cm}^{3}$ and bowl diameters of 55.0 and $67.5 \mathrm{~mm}$, respectively; cylinder heads providing a 3.0-4.0 swirl ratio for Common Rail system, 3.5-4.5 for mechanical injection system. The recirculation rate was set by gas throttling before the turbine using a rotary valve of an original design. The tests have been conducted at characteristic points of the NRSC cycle: minimum idle speed $800 \mathrm{rpm}$, maximum torque speed $1600 \mathrm{rpm}$, rated power speed $2100 \mathrm{rpm}$. It has been established that it is possible to achieve the standards of emissions of harmful substances: on the $116 \mathrm{~kW}$ diesel engine using of direct-action fuel equipment and a semi-open combustion chamber; on the $156 \mathrm{~kW}$ diesel using Common Rail fuel supply system of the Low Cost type and an open combustion chamber.
\end{abstract}

Keywords: diesel, swirl ratio, combustion chamber, fuel supply system, fuel sprayer

For citation: Kuharonak G. M., Klesso M., Predko A., Telyuk D. (2021) Organization of Six-Cylinder Tractor Diesel Working Process. Science and Technique. 20 (5), 427-433. https://doi.org/10.21122/2227-1031-2021-20-5-427-433

\section{Организация рабочего процесса шестицилиндрового тракторного дизеля}

\author{
Докт. техн. наук, проф. Г. М. Кухаренок', \\ М. Клессо 2 , А. Предко ${ }^{2)}$, Д. Телюк 2$)$ \\ ${ }^{1)}$ Белорусский национальный технический университет (Минск, Республика Беларусь), \\ ${ }^{2)} \mathrm{OAO}$ «УКХ «Минский моторный завод» (Минск, Республика Беларусь)
}

Реферат. Рассмотрена организация рабочего процесса шестицилиндровых дизелей мощностью 116 и 156 кВт с рециркуляцией отработавших газов. В экспериментальных комплектациях двигателя использовались следующие системы и узлы: аккумуляторная система подачи топлива Common Rail BOSCH с давлением впрыска 140 MПа, оснащенная электрогидравлическими форсунками с семисопловыми отверстиями и проливом 500 мм $^{3}$; система впрыска непосредственного действия с топливным насосом MOTORPAL c максимальным давлением впрыска 100 MПа, оснащенная форсунками MOTORPAL и AЗПИ с пятисопловыми отверстиями; камеры сгорания двух типов объемами 55 и $56 \mathrm{~cm}^{3}$ с диаметрами горловин 55,0 и 67,5 мм; головки блоков цилиндра, обеспечивающие вихревое отношение для системы впрыска Common Rail 3.0-4.0, для механической системы впрыска 3,5-4,5. Степень рециркуляции задавалась дросселированием отработавших газов перед турбиной с помощью заслонки оригинальной конструкции. Испытания проводились по характерным точкам цикла NRSC на трех частотах вращения коленчатого вала: минимальной холостого хода 800 мин $^{-1}$, максимальной крутящего момента 1600 мин $^{-1}$ и максимальной мощности 2100 мин $^{-1}$. Установлено, что достижение норм выбросов вредных веществ возможно: на дизелях

\section{Адрес для переписки}

Кухаренок Георгий Михайлович

Белорусский национальный технический университет

ул. Я. Коласа, 12,

220013, г. Минск, Республика Беларусь

Тел.: +375 17 292-81-86

kux@tut.by

\author{
Address for correspondence \\ Kuharonak Georgy M. \\ Belarusian National Technical University \\ 12, Ya. Kolasa str., \\ 220013, Minsk, Republic of Belarus \\ Tel.: +375 17 292-81-86 \\ kux@tut.by
}


мощностью 116 кВт с использованием топливной аппаратуры непосредственного действия и с полуоткрытой камерой сгорания; на дизелях мощностью 156 кВт с использованием системы топливоподачи Common Rail типа Low Cost и открытой камерой сгорания.

Ключевые слова: дизель, вихревое отношение, камера сгорания, система топливоподачи, распылитель топлива

Для цитирования: Организация рабочего процесса шестицилиндрового тракторного дизеля / Г. М. Кухаренок [и др.] // Наука и техника. 2021. Т. 20, № 5. С. 427-433. https://doi.org/10.21122/2227-1031-2021-20-5-427-433

\section{Introduction}

The diesel engine building is one of the main areas of mechanical engineering developed recently in the Republic of Belarus. Minsk Motor Plant is the oldest enterprise in the republic, which produces multi-purpose diesel engines in a wide power range (Fig. 1) for 56 years. The enterprise development strategy, implemented within the framework of plant and state scientific and technical programs, is aimed at producing competitive products that meet modern technical requirements of international standards and quality [1].

The technical regulations of the Customs Union require newly manufactured or imported new tractors diesel engines to comply with Stage 3A environmental standards, which should increase the demand for diesel engines of this ecological class [2-9]. Two modifications of six-cylinder tractor diesel engines are currently in greatest demand: D-260.1S3A with a power of $116 \mathrm{~kW}$ and D-260.4S3A with a power of $156 \mathrm{~kW}$.

a
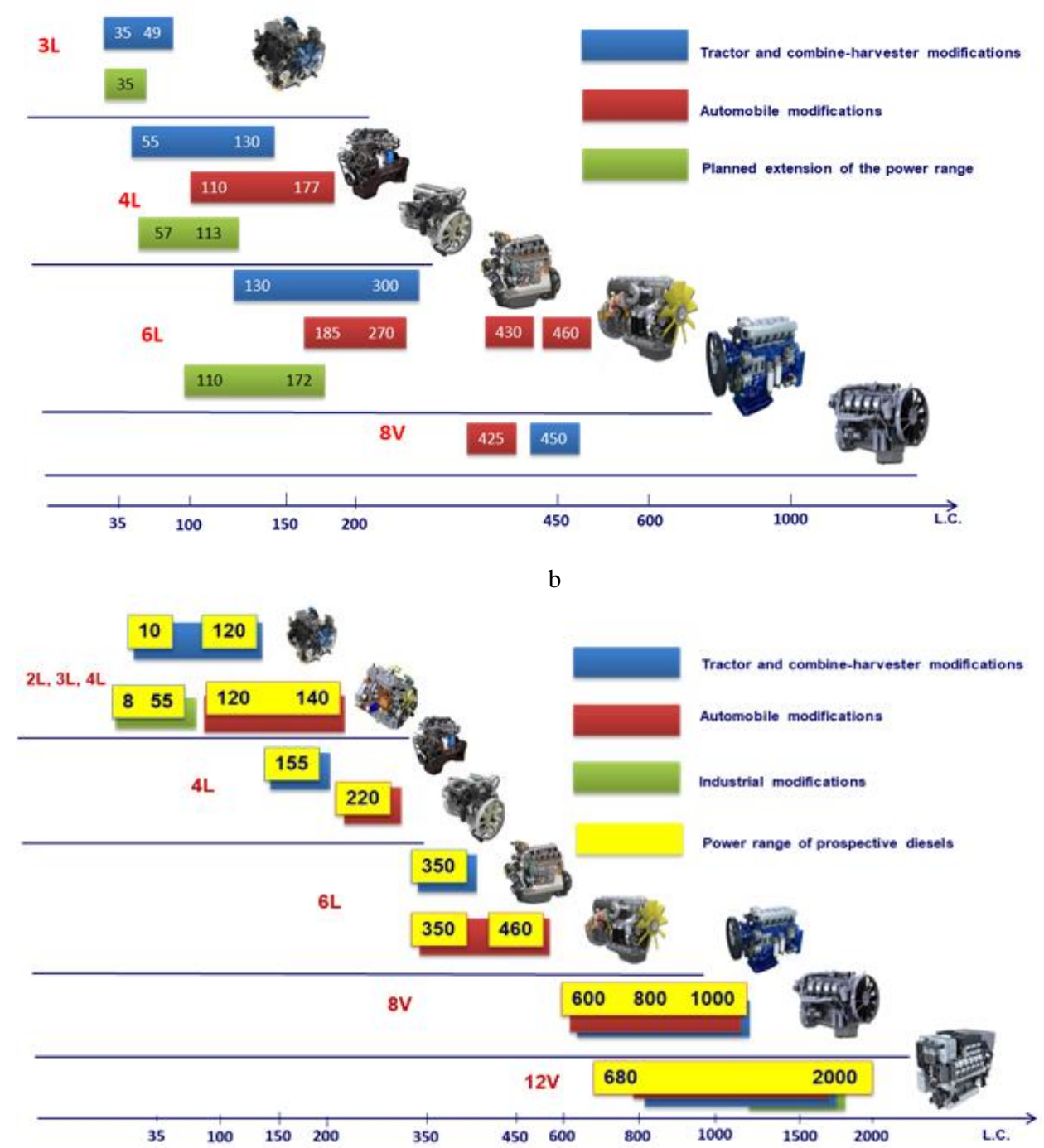

Fig. 1. Power range of the engines manufactured by Minsk Motor Plant: $a$ - serial engines; $b$ - promising 


\section{Main part}

The environmental performance of the Stage 3A level is achieved mainly by coordinating the combustion chamber shape, the fuel supply equipment parameters, the intake ports swirl ratio, the valve timing and the use of exhaust gas recirculation (EGR) [1, 10-16].

D-260 engines use cylinder heads with two valves per cylinder, which should ensure the simplicity of the gas distribution mechanism design and maintenance. The somewhat increased resistance of the gas exchange channels is compensated to some extent by engine boost. The inlet channels are bifunctional - screw. When profiling the channels, the correctness of the adopted structural decisions is checked by 3D-modeling of the gas flow at given pressure drops (Fig. 2) with the determination of air flow and the average angular velocity of the air charge.

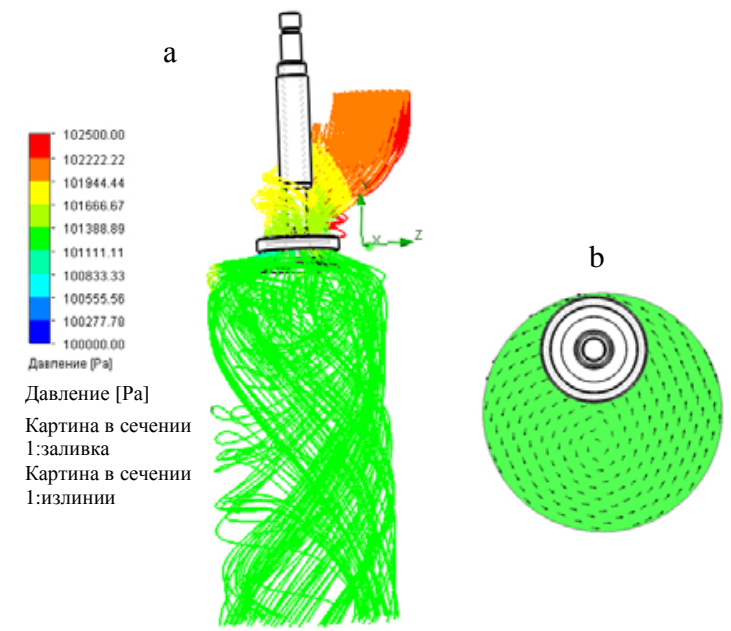

Fig. 2. Results of the inlet channel virtual purge: $\mathrm{a}$ - pressure distribution; $\mathrm{b}$ - velocity field in the outlet section

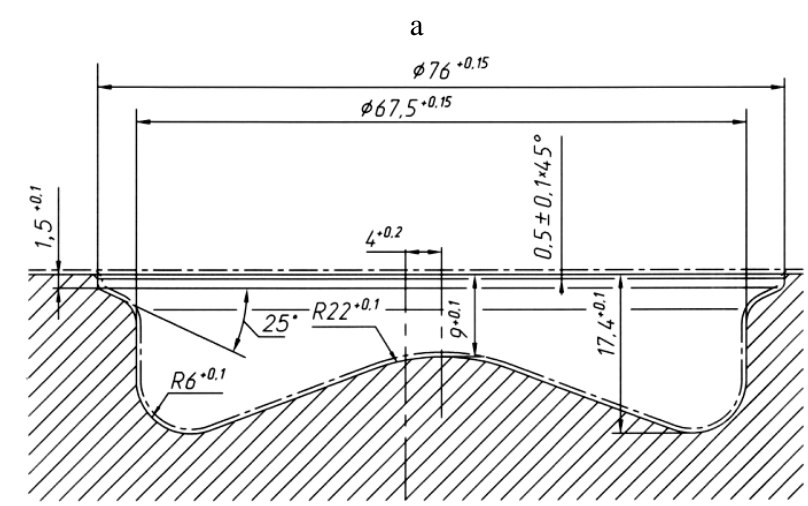

The mathematical model of a viscous heatconducting fluid flow is based on the Navier Stokes equations system, combining the laws of mass, momentum and energy conservation of a fluid in an unsteady setting [17-21].

To control the parameters of the cast heads inlet channels, a non-motorized purge stand with a straightening grate is used [22]. Typically, the data of virtual and natural purges differ by no more than $5 \%$. For D-260 engines, the head designs have been developed that provide an air swirl generation at the inlet with a swirl ratio of 3.0-4.0 and 3.5-4.5.

Heads with a lower swirl ratio are used on engines equipped with accumulator fuel systems with high injection rates and open combustion chambers (Fig. 3a) [23, 24]. Large swirl ratios are used for engines with direct-acting fuel equipment and a semi-open combustion chamber (Fig. 3b) [25].

The commercially available satisfying Stage 3A environmental standards six-cylinder D-260 diesel engines are equipped with: BOSCH Common Rail fuel supply system with electronic control; pistons with an open combustion chamber; a cylinder head with a screw inlet channel providing a swirl ratio $H=3.0-4.0$; unregulated turbo charging. Low pressure EGR is used to reduce $\mathrm{NO}_{x}$ emissions [26].

In order to increase the competitive attractiveness of six-cylinder engines, it was decided to use fuel supply systems of a lower price category a fuel supply system with a direct-acting pump and a mechanical regulator manufactured by MOTORPAL. The fuel supply system layout with a direct-acting pump is shown in Fig. 4.

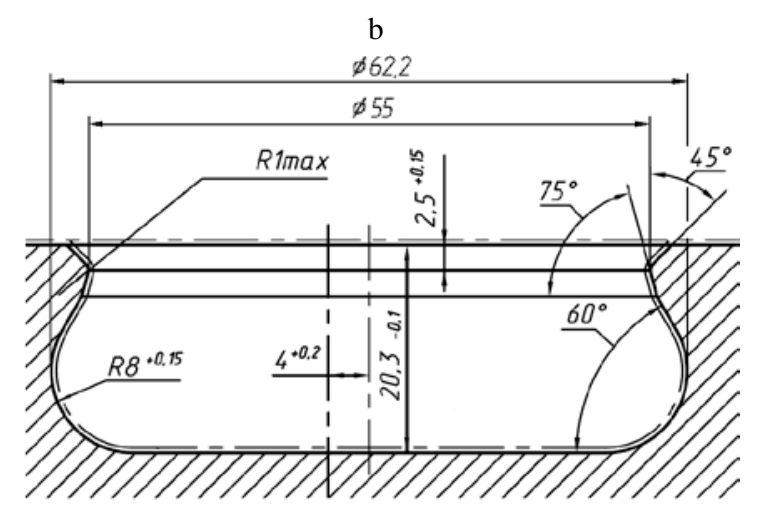

Fig. 3. Combustion chambers: a - open combustion chamber; b - semi-open combustion chamber 


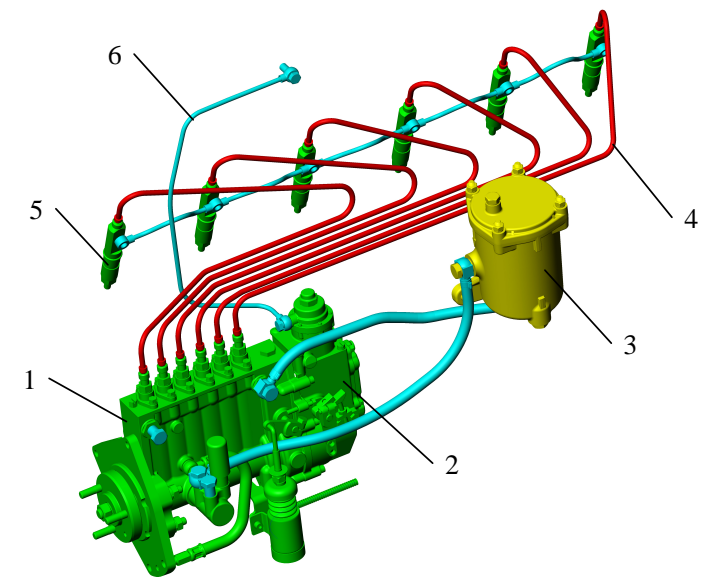

Fig. 4. Fuel supply system layout with a MOTORPAL pump: 1 - high pressure fuel pump; 2 - speed governor; 3 - fuel filter; 4 - high pressure fuel line; 5 - injector; 6 - tube to the corrector for charge air pressure

The fuel pump 6M4330ZT (MOTORPAL, Czech Republic) with a diameter of $10 \mathrm{~mm}$ and a stroke of $14 \mathrm{~mm}$ of the plunger is equipped with a mechanical governor and a fuel feed corrector by the charge air pressure. The maximum fuel injection pressure is $100 \mathrm{MPa}$. When developing the working process on a $116 \mathrm{~kW}$ diesel engine, three sets of hydromechanical injectors were used:

-injectors VA70P360 with nozzles DOP147P528 $\left(\mu \mathrm{f}=0.22 \mathrm{~mm}^{2}\right)$ (MOTORPAL, Czech Republic) (Fig. 5a) (for an open combustion chamber);

- injectors VA70P360 with sac-less nozzles DOP140P528 ( $\left.\mu \mathrm{f}=0.18-0.20 \mathrm{~mm}^{2}\right)$ (MOTORPAL, Czech Republic) (Fig. 5b);

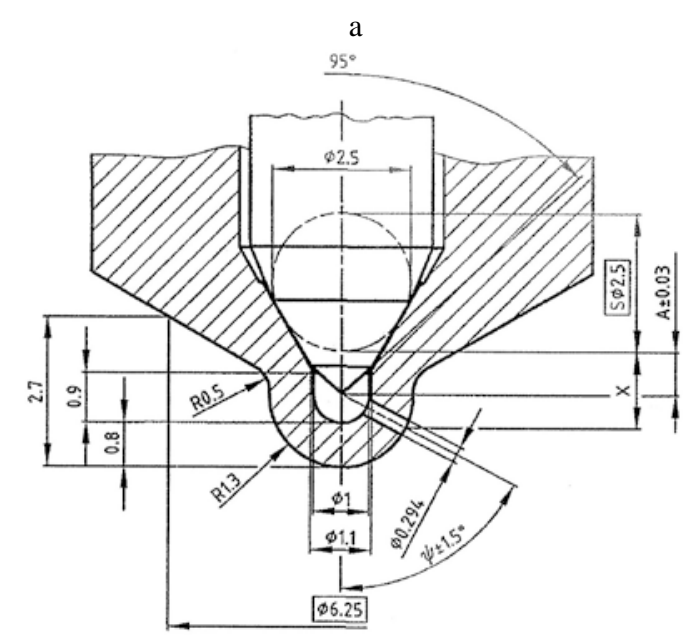

- injectors AZPI 172.1112010-11.01 with nozzles AZPI 172.1112110-12.01 $\left(\mu \mathrm{f}=0.23-0.25 \mathrm{~mm}^{2}\right)$.

Matching of the combustion chamber shape and the fuel flames location was carried out using 3D-models [24, 27]. The places where the fuel jets axes meet the combustion chamber walls are shown in Fig. 6.

The comparative tests (Tab. 1) for the NRSC cycle showed the possibility of achieving emission standards for Stage 3A. The use of sac-less nozzles led to a decrease in fuel leakage and, as a consequence, to a decrease in nozzles coking, soot and $\mathrm{CH}_{x}$ hydrocarbons emissions [12, 28]. Tests of the D-260.4S3A diesel engine with direct-acting fuel equipment showed a high exhaust smoke level while ensuring the target $\mathrm{NO}_{x}$ emissions (Tab. 1) using the EGR. As a result, achieving the Stage 3A level for particulate emissions on a D-260.4 engine with a direct-acting fuel system with semi-open and open combustion chambers is not possible at this stage. Therefore, the proposed use of the type Low Cost Common Rail accumulator system.

The schematic diagram of the type Low Cost Common Rail system is shown in Fig. 7. It includes:

- the fuel pump CB 28;

- injectors CRIN2 with seven-hole nozzles A433 205533 (jet cone angle $\delta=147.6^{\circ}$ and a hydraulic flow of $\left.500 \mathrm{~cm}^{3} / 30 \mathrm{~s} / 100 \mathrm{bar}\right)$;

- the pressure accumulator LWRN18 with a maximum injection pressure of 1400 bar;

- the control unit EDC17CV54 with software version P_1142.3.0.0 for the Low Cost system.

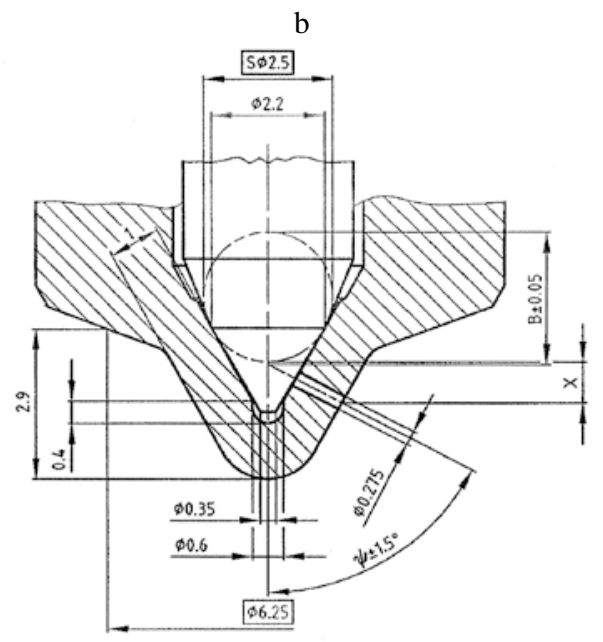

Fig. 5. Nozzle cone shapes: a - with a blind-hole (with a dead volume); $\mathrm{b}$ - with the exit of nozzle holes to the surface of the locking cone (sac-less nozzle) 
a
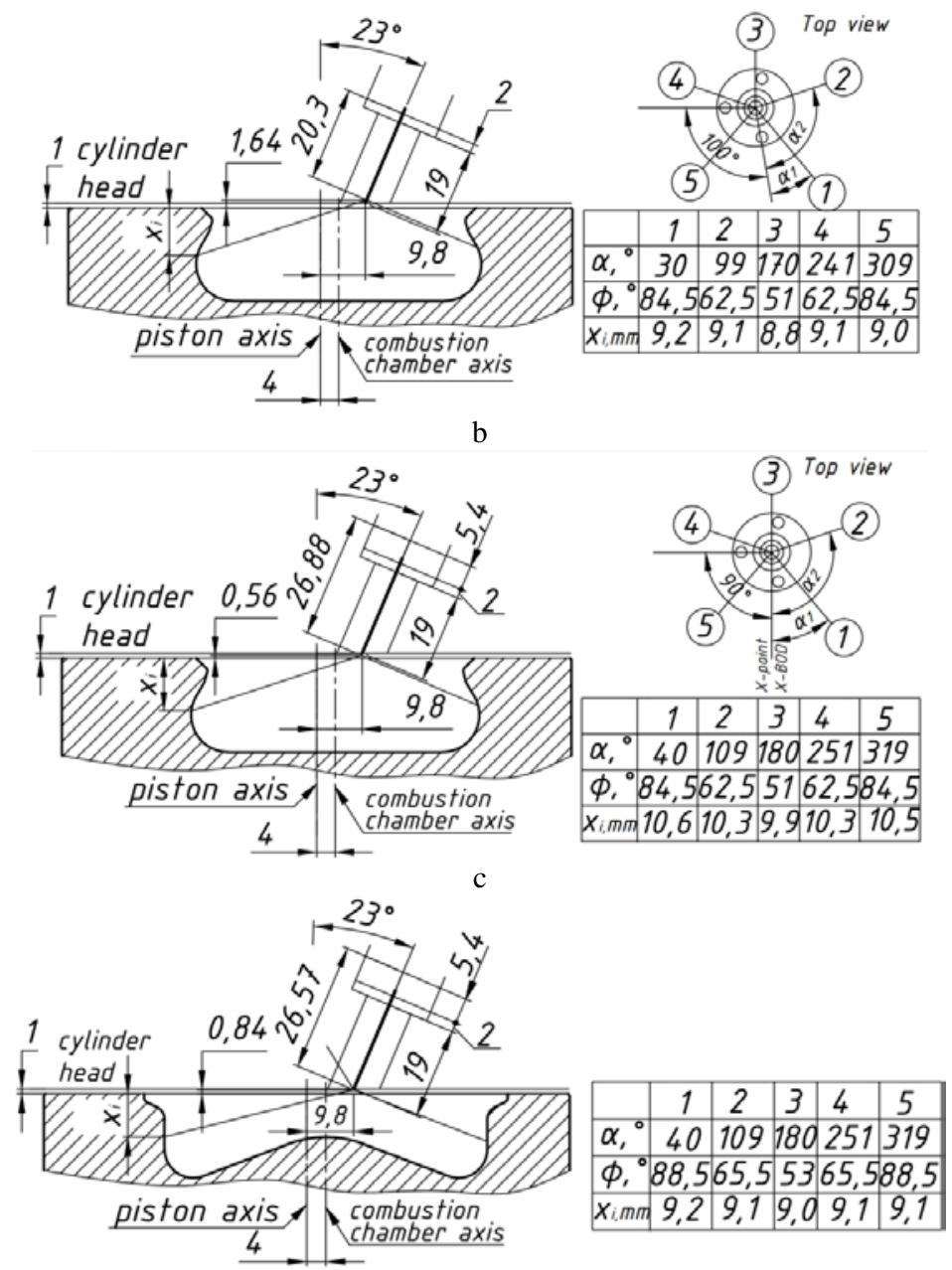

Fig. 6. Determination of the points of intersection of the fuel flames axes with the combustion chambers walls: a - AZPI 172.1112110-12.01 nozzle; b - MOTORPAL DOP140P528; c - MOTORPAL DOP147P528

Results of D-260.1 and D-260.4 diesel engines comparative tests with various nozzles and combustion chambers according to the NRSC cycle

\begin{tabular}{|c|c|c|c|c|c|c|c|c|}
\hline Diesel & Options & $\begin{array}{c}g_{\mathrm{CH}}, \\
\mathrm{g} /(\mathrm{kW} \cdot \mathrm{h})\end{array}$ & $\begin{array}{c}g_{\mathrm{NOx}} \\
\mathrm{g} /(\mathrm{kW} \cdot \mathrm{h})\end{array}$ & $\begin{array}{c}g_{\mathrm{SC}} \\
\mathrm{g} /(\mathrm{kW} \cdot \mathrm{h})\end{array}$ & $\begin{array}{c}g_{e \mathrm{RP}} \\
\mathrm{g} /(\mathrm{kW} \cdot \mathrm{h})\end{array}$ & $\begin{array}{c}g_{e T \max }, \\
\mathrm{g} /(\mathrm{kW} \cdot \mathrm{h})\end{array}$ & $N_{\mathrm{RP}}, \% \mathrm{HSU}$ & $\begin{array}{l}N_{T \max }, \\
\text { \%HSU }\end{array}$ \\
\hline \multirow{3}{*}{  } & $\begin{array}{l}\text { Nozzles } \\
\text { AZPI 172.1112110-12.01 }\end{array}$ & 0.48 & 3.43 & 0.240 & 228.4 & 204.9 & 7.9 & 9.1 \\
\hline & Nozzles DOP140P528 & 0.21 & 3.84 & 0.164 & 229.9 & 204.5 & 6.6 & 4.3 \\
\hline & UNECE Regulation No 96 (02) & \multicolumn{2}{|c|}{$4.0\left(\mathrm{NO}_{x}+\mathrm{CH}\right)$} & 0.300 & \multicolumn{4}{|c|}{-} \\
\hline \multirow{3}{*}{ 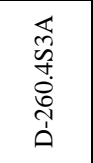 } & Nozzles DOP140P528 & - & 3.42 & 0.360 & 229.3 & 215.6 & 16.5 & 17.8 \\
\hline & $\begin{array}{l}\text { Nozzles DOP147P528, } \\
\text { open combustion chamber }\end{array}$ & - & 3.46 & 0.338 & 229.2 & 216.0 & 12.8 & 17.6 \\
\hline & UNECE Regulation No 96 (02) & \multicolumn{2}{|c|}{$4.0\left(\mathrm{NO}_{x}+\mathrm{CH}\right)$} & 0.200 & \multicolumn{4}{|c|}{-} \\
\hline
\end{tabular}

To increase the recirculation and turbocharging units reliability, a transition to the highpressure EGR system, the diagram of which is shown in Fig. 8 [26, 29, 30]. In the high-pressure EGR system, the recirculated exhaust gases do not pass through the turbocharging units, which should have a positive effect on the operating conditions of the charge air cooler and compressor. However, in order to obtain the required gas cooling depth, the size of the standard built into the catchment pipe cooler is not enough. Therefore, an additional EGR cooler (similar to the serial one with four-cylinder engines) is included in the experimental setup. 


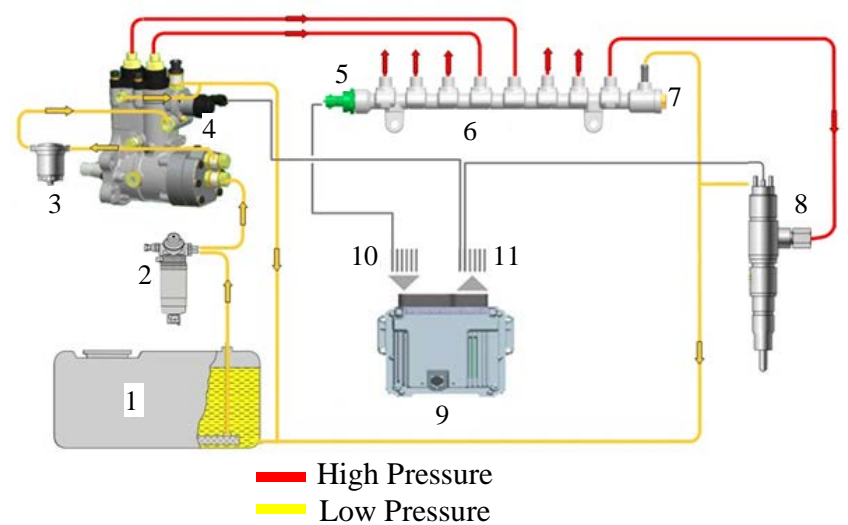

Fig. 7. Diagram of the Common Rail fuel system: 1 - fuel tank; 2 - coarse filter; 3 - fine filter; 4 - fuel pump; 5 - fuel pressure sensor; 6 - fuel rail; 7 - pressure-relief valve; 8 - injector; 9 - electronic control unit;

10 - signals from sensors; 11 - signals to actuators

Tests of six-cylinder diesel engines with the high-pressure EGR system showed the problem of organization the EGR gas flow in the right direction. In some operating modes, the charge air pressure is higher than the exhaust pressure upstream the turbine. To create the necessary pressure difference, an additional rotary valve was introduced into the recirculation system, which prevents the free passage of exhaust to the turbine. As a result of testing a diesel engine with a Low Cost type Common Rail system and the rotary EGR valve, the rotary valve positions were determined and turbocharging units were selected to achieve Stage 3A level for exhaust emissions. The test results of the engine D-260.4S3A are presented in Tab. 2.

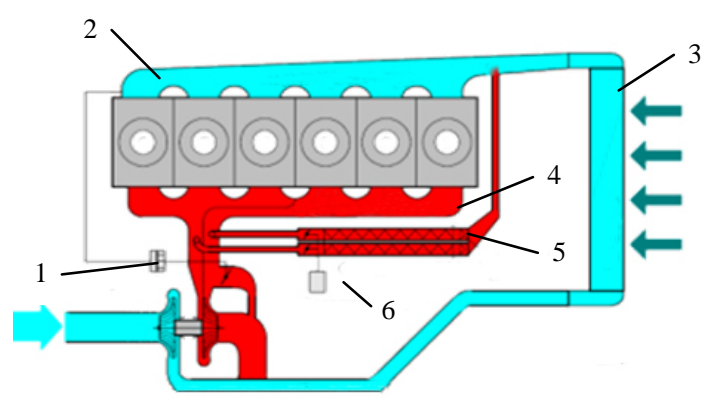

Fig. 8. Schematic diagram of the high-pressure EGR system: 1 - bypass valve; 2 - inlet manifold; 3 - charge air cooler; 4 - exhaust manifold; 5 - EGR cooler; 6 - rotary EGR valve

Table 2

Results of D-260.4S3A diesel tests with a Common Rail fuel system on the NRSC cycle

\begin{tabular}{|c|c|c|c|c|c|c|c|c|c|c|}
\hline \multirow{2}{*}{\multicolumn{2}{|c|}{ Parameters }} & \multicolumn{8}{|c|}{ Cycle Point } & \multirow{2}{*}{ Per Cycle } \\
\hline & & 1 & 2 & 3 & 4 & 5 & 6 & 7 & 8 & \\
\hline \multicolumn{2}{|l|}{$n, \mathrm{rpm}$} & 2100 & 2100 & 2100 & 2100 & 1600 & 1600 & 1600 & 800 & - \\
\hline \multicolumn{2}{|l|}{$M_{k}, \mathrm{~N} \cdot \mathrm{m}$} & 706 & 530 & 353 & 71 & 899 & 690 & 460 & 0 & - \\
\hline \multicolumn{2}{|l|}{$\alpha_{\text {EGRvalve, }} \%$ op. } & 35 & 80 & 80 & 100 & 65 & 85 & 82 & 100 & - \\
\hline \multicolumn{2}{|l|}{$g_{e}, \mathrm{~g} /(\mathrm{kW} \cdot \mathrm{h})$} & 220.5 & 227.1 & 243.4 & 472.6 & 221.7 & 219.7 & 227.9 & - & - \\
\hline \multicolumn{2}{|l|}{$N, \% \mathrm{HSU}$} & 5.7 & 5.7 & 3.9 & 0.8 & 7.2 & 6.8 & 7.2 & 0.6 & - \\
\hline \multicolumn{2}{|l|}{$g_{\mathrm{NOx}}, \mathrm{g} /(\mathrm{kW} \cdot \mathrm{h})$} & 4.61 & 2.57 & 2.00 & 3.25 & 4.39 & 2.47 & 1.69 & - & 3.30 \\
\hline \multicolumn{2}{|l|}{$g_{\mathrm{SC}}, \mathrm{g} /(\mathrm{kW} \cdot \mathrm{h})$} & 0.136 & 0.146 & 0.111 & 0.031 & 0.148 & 0.141 & 0.168 & - & 0.138 \\
\hline \multirow{2}{*}{$\begin{array}{l}\text { UNECE Regulation } \\
\text { No 96(02) }\end{array}$} & $g_{\mathrm{NO} x+\mathrm{CH}}, \mathrm{g} /(\mathrm{kW} \cdot \mathrm{h})$ & \multicolumn{8}{|c|}{-} & 4.0 \\
\hline & $g_{\mathrm{SC}}, \mathrm{g} /(\mathrm{kW} \cdot \mathrm{h})$ & \multicolumn{8}{|c|}{-} & 0.2 \\
\hline
\end{tabular}

\section{CONCLUSION}

Measures have been developed to organize the six-cylinder tractor diesel engines working process of the ecological level Stage 3A with high-pressure exhaust gas recirculation. It has been established that the achievement of emission standards on diesel engines with a power of $116 \mathrm{~kW}$ is possible using direct-acting fuel equipment and a semi-open combustion chamber. To comply with Stage 3A on $156 \mathrm{~kW}$ diesel engines, the use of a Low Cost type Common Rail fuel system with an open combustion chamber is required.

\section{REFERENCES}

1. Sevizdral S. P., Berezun V. I. (2013) State of Issue and Prospects for Development of Engine-Building in the Re- public of Belarus. Zhurnal Assotsiatsii Avtomobilnykh Inzhenerov = Zurnal AAI, (6), 6-7 (in Russian).

2. Eurasian Economic Commission (2012) TR TS 031/2012. On Safety of Agricultural and Forestry Tractors and Trailers to Them. Minsk, Ekonomenergo Publ. 60 (in Russian).

3. United Nations (1986) Agreement Concerning the Adoption of Uniform Conditions of Approval and Reciprocal Recognition of Approval for Motor Vehicle Equipment and Parts. Done at Geneva on 20 March 1958. Addendum 23: Regulation No 24 to be Annexed to the Agreement Revision 2 Incorporating the 03 Series of Amendments which Entered into Force on 20 April 1986. Available at: https://unece.org/ fileadmin/DAM/trans/main/wp29/wp29regs/r024r2e.pdf.

4. United Nations (2013) Concerning the Adoption of Uniform Technical Prescriptions for Wheeled Vehicles, Equipment and Parts which Can be Fitted and/or be Used on Wheeled Vehicles and the Conditions for Reciprocal Recognition of Approvals Granted on the Basis of these Prescriptions. (Revision 2, Including the Amendments which Entered into Force on 16 October 1995). Addendum 95 - 
Regulation No 96. Revision 2 - Amendment 1 Supplement 1 to the 03 Series of Amendments - Date of Entry into Force: 15 July 2013. Uniform Provisions Concerning the Approval of Compression Ignition (C.I.) Engines to be Installed in Agricultural and Forestry Tractors and in Non-Road Mobile Machinery with Regard to the Emissions of Pollutants by the Engine. Available at: https://unece. org/fileadmin/DAM/trans/main/wp29/wp29regs/2013/R09 6r2am1e.pdf.

5. Markov V. A., Bashirov R. M., Gabitov I. I. (2002) Diesel Exhaust Gas Toxicity. Moscow, Publishing House of Bauman Moscow State Technical University. 376 (in Russian).

6. Basshuysen R., Schäfer F. (2007) Handbuch Verbrennungsmotor. Grundlagen, Komponenten, Systeme, Perspektiven. Auflage. Wiesbaden, Vieweg \& Sohn Verlag. 1032 (in German).

7. Zvonov V. A., Zaigraev L. S., Chernykh V. I., Kozlov, A. V. (2004) Ecology of Automotive Internal Combustion Engine. Lugansk: Publishing House of Volodymyr Dahl East Ukrainian National University. 268 (in Russian).

8. Parsadanov I. V. (2003) Improvement of Quality and Competitiveness of Diesel Engines Based on the Fuel and Environmental Criterion. Kharkov, Publishing Centre of National Technical University "Kharkiv Polytechnic Institute”. 244 (in Russian).

9. Kulchitskii A. R. (2000) Toxicity of Automotive and Tractor Engines. Vladimir, Vladimir State University. 256 (in Russian).

10. Kukharonak G. M., Berezun V. I. (2013) Diesel Emission Reduction. Sovershenstvovanie Organizatsii Dorozhnogo Dvizheniya i Perevozok Passazhirov i Gruzov: Sbornik Nauchnykh Trudov [Improvement in Organization of Traffic and Transport of Passengers and Goods. Collection of Scientific Papers]. Minsk, Belarusian National Technical University, 314-323 (in Russian).

11. Berezun V. I. (2013) High-Performance Energy-Efficient Engines for Off-Road Vehicles. Problems and Prospects for Development of Transport Systems and Building Complex. Gomel, Belarusian State University of Transportation, 157-158 (in Russian).

12. Bosch R. (2004) Diesel Engine Control Systems. Moscow, Publishing House "Za Rulyom”. 480 (in Russian).

13. Kukharonak G. M., Berezun V. I. (2018) Influence of Fuel Supply and Exhaust Gas Recirculation on Emissions of Harmful Substances from Diesel Engines. Avtomobil'nyi Transport [Automotive Transport], (42), 5-11 (in Russian).

14. Kukharonak G. M., Petruchenko A. N., Berezun V. I. (2014) Diesel Engine Emissions Reduction. Moscow, Novoe Znanie Publ. 220 (in Russian).

15. Kukharonak G. M., Sevizdral S. P., Berezun V. I. (2012) Provision of Environmental Indicators of Euro-4 and Euro-5 Level for Automobile Diesels of the Minsk Motor Plant. Visti Avtomobilno-Dorozhniogo Institutu [Bulletin of Automobile and Highway Institue], (1), 95-105 (in Russian).

16. Kukharonak G. M., Berezun V. I. (2018) Improvement of Diesel Engine Workflow. Izobretatel [Inventor], (1), 37-40 (in Russian).

17. Kukharonak G. M., Predko A. V. (2002) Mathematical Model of Rotation of Air Charge in Diesel Cylinder. Vestnik BNTU [Bulletin of Belarusian National Technical University], (4), 50-54 (in Russian).

18. Predko A. V. (2006) Modeling Flow in Inlet of Internal Combustion Engine. Nauka - Obrazovaniyu, Proizvodstvu, Ekonomike: Materialy 4-i Mezhdunar. Nauch.-Tekhn. Konf. T. 1 [Science for Education, Production, Economy. Proceedings of the $4^{\text {th }}$ International Scientific and Technical Confe- rence. Vol. 1]. Minsk, Belarusian National Technical University, 262-265 (in Russian).

19. Kukharonak G. M., Predko A. V., Yurchuk K. N. (2008) Determination of Parameters of Inlet Channels Using Virtual Bench in Purge. Vmeste k Effektivnomu Dvizheniyu! Sb. Nauch. Statei Mezhdunar. Nauch.-Prakt. Konf. [Together for Effective Movement! Collection of Scientific Papers of International Scientific and Practical Conference]. Minsk, Belarusian National Technical University, 262-265 (in Russian).

20. Alyamovskii A. A., Sobachkin A. A., Odintsov E. V., Kharitonovich A. I., Ponomarev N. B. (2005) SolidWorks. Computer Modeling in Engineering Practice. Saints-Petersburg, Publishing House "BKhV-Peterburg". 800 (in Russian).

21. Deich M. E. (1969) Technical Gas Dynamics. Moscow, Energiya Publ. 368 (in Russian).

22. Predko A. V. (1995) Methods for Experimental Study of Swirling Inlet Channels. Sostoyanie i Perspektivy Razvitiya Nauki i Podgotovki Inzhenerov Vysokoi Kvalifikatsii v BGPA. Materialy Mezhdunar. 51-i Nauch.-Tekhn. Konf. BGPA [State and Prospects for Development of Science and Training of Highly Qualified Engineers at Belarusian State Polytechnical Academy. Proceedings of the $51^{\text {st }} \mathrm{In}$ ternational Scientific and Technical Conference at BSPA]. Minsk, Belarusian State Polytechnical Academy, 78-79 (in Russian).

23. Kukharonak G. M., Petruchenko A. N., Berezun V. I. (2014) Choice of Diesel Engine Combustion Chamber Shape. Visnik SevNTU [Bulletin of Sevastopol National Technical University], (152), 65-68 (in Russian).

24. Kukharonak G. M., Hershan D. G. (2011) Modeling of Characteristics for Fuel Jets and Parameters for Diesel Combustion Chamber. Vestnik BNTU [Bulletin of Belarusian National Technical University], (4), 35-39 (in Russian).

25. Kukharonak G. M., Berezun V. I. (2014) Choice of Shape for Combustion Chamber of Diesel Engine with Low Injection Intensity. Sovershenstvovanie Organizatsii Dorozhnogo Dvizheniya i Perevozok Passazhirov i Gruzov: Sb. Nauch. Tr. [Improvement in Organization of Traffic and Transport of Passengers and Goods. Collection of Scientific Papers]. Minsk, Belarusian National Technical University, 180-184 (in Russian).

26. Kukharonak G. M., Berezun V. I. (2018) Influence of Fuel Supply and Exhaust Gas Recirculation on Emissions of Harmful Substances from Diesel Engines. Avtomobil'nyi Transport [Automotive Transport], (42), 5-11 (in Russian).

27. Kukharonak G. M. (1999) High Speed Diesel Workflow. Methods and Means of Improvement. Minsk, Belarusian State Polytechnical Academy. 180 (in Russian).

28. Grekhov L. V., Ivashchenko N. A., Markov V. A. (2004) Fuel Equipment and Diesel Control System. Moscow, Legion-Avtodata Publ. 344 (in Russian).

29. Kukharonak G. M., Berezun V. I. (2014) Selection of Parameters for System of Diesel Engine Exhaust Gas Recirculation. Nauka i Tekhnika = Science \& Technique, (1), 57-63 (in Russian).

30. Berezun V. I. (2014) Study of Methods for Organizing Exhaust Gas Recirculation. Nauka - Obrazovaniyu, Proizvodstvu, Ekonomike: Materialy 12-i Mezhdunar. Nauch.-Tekhn. Konf. T. 2 [Science for Education, Production, Economy: Proceedings of the $12^{\text {th }}$ International Scientific and Technical Conference. Vol. 2]. Minsk, Belarusian National Technical University, 56-57 (in Russian).

Received: 11.11.2020

Accepted: 25.01.2021 Published online: 30.09 .2021 